\title{
Dance and Gender Relations: A Reflection on the Interaction between Male and Female Students in Dance Classes
}

\author{
Giuliano Souza Andreoli \\ Assistant Professor \\ State University of Rio Grande do Sul of Brazil
}

\begin{abstract}
:
This article presents a research that aimed at understanding how dance classes can be set up as a space for gendering experiences. To approach it, the concept of gender is used. By analyzing observations carried out on dance classes of PIBID project, as developed by Universidade Estadual do Rio Grande do Sul (RS, Brazil), reflections approach the scenes in which gender relations are constituted, and implied on thinking and creating dance. Results show that there are hierarchies between male and female students in the context of dance classes, as well as gendered ways of organizing dance practices, although some changes in the way teachers intervene have already started.
\end{abstract}

Keywords: dance; gender; education.

This article is based on a research that was developed with the goal of observing and analyzing body gendering constitution and subject positions of male and female students, following the school syllabus of the early years of elementary school. In the research, classes were taught by undergraduates of a university level Teaching Training Program in Dance. These teachers work for the Institutional Program of Teaching Grants (PIBID in the Portuguese acronym) at Campus Montenegro II of Universidade Estadual do Rio Grande do Sul, RS, Brazil.

First, the concept of gender is presented. Then, focus is on the relation between dance and education. Next, research methodology, field, and goals are presented. Finally, results of observations carried out during classes of teachers-to-be who were subscribed to the teaching foundations program in 2017 are presented. By analyzingsome everyday microscopic situations in dance classes, my goal is to dimension gender as part of the schooling process for male and female students.

\section{The Concept of Gender:}

For the purposes of this article, gender means the cultural construct of meaning, symbols and norms that originate "masculinities" and "femininities" (Scott 1995; Butler 2010; Louro 2007).Therefore, gender is different from "sex", as this term is used in natural sciences to designate biological differences between men and women, thus referring to socio-cultural differences (Scott 1995; Louro 2007).It is then a concept that operates by "rejecting the biological determinism that is implicit in the terms 'sex' and 'sexual difference'." (Scott 1995, 72).

For Butler (2010), the subject of gender is an effect, produced by repeating acts that correspond to social and cultural norms. Thus, gender is not the expression of what men and women are in essence, but the very cultural performance that allows for the maintenance of such norms. These norms, on their turn, establish a binary opposition in our culture, based on a "fallocentric" cultural logic:the dichotomy and hierarchy between "masculinity" and "femininity".

For example, fallocentrism was already present in Aristotle, who expressed a common and widespread conception in the ancient Greek world: that women were men whose development was halted before being finished, rendering them unable to achieve their perfect form because the cold maternal womb subdued the father's warm seed (Correia 2004, 31). Until the eighteenth century, in Medicine, women were understood to be lesser men. The womb was the female scrotum; ovaries were testicles, the vulva was the foreskin, and a vagina was in fact a penis, all inside out. Thus conceived as inverted men, women were less developed and less perfect organisms. Male anatomy was the model of perfection (Laqueur 2001). Hegemonic representations of gender, as heritage to such cultural logic, conceive of masculitinies and femininities as polar, where the masculine end is worthier.

Besides, in our civilization, gender is governed by the cultural logic of heteronormativity (Butler 2010). Such assumption, that heterossexuality is "normal", and thus any other kind is a deviation, is a gender regulation mechanism that gives birth to homophobic behavior. Homophobia is described by Britzman as "the obsession with normalizing sexuality, by means of discourse that describes homoerotic affairs as deviation" (Britzman 1996, 79). 
This way, the concept of gender can be used to legitimize imbalanced and violent relations (whether concrete or symbolic), acting as a cause of social inequalities: a) sex-related inequality, that is, rankings, hierarchies and exclusions based on binary distinction between men and women; and b) exclusion of non-heterossexuality, which deviate from heteronormalcy. Besides, as Butler $(2001,2010)$ states:

Gender must not be merely conceived of as the cultural inscription of meaning in a previously given sex [...] it also must designate the very apparatus of production by which the very sexes are established. (Butler 2010, 25).

Discourses convert certain parts of the human body, such as genitalia, in gender-defining marks. This way, cisgender people are those who keep a privileged state over 'transgender' people, since they are socially seen as "aligned" between body and gender (Butler 2001; Louro 2013b; Preciado 2014). This deterministic relation between biological sex and gender imposes "cisnormativity". Captured inside such devices, transexuals are those who Butler $(2001,171)$ calls "weightless bodies", bodies that do not count and thus can be discarded.

Therefore, this perspective calls into question the universality of the categories "man" and "woman", which are linked to binary oppositions that associate power and domination to men, and submission to women. Gender is understood as a form of relation (Scott 1995). It institutionalizes far more complex power relations, which include not only the command of men over women, but also women's consent and adherence, or coercion of men that do not include themselves in dominant male standards. In this regard, the term gender also implies something that goes beyond the mere performance of social "roles" (Louro 2007), for the discourses that represent and contextualize the significance of being male or female take place in various social spaces and circumstances.

In this sense, gender is understood to relate to social organization as a whole, as well as to social institutions (education system, political system, etc.), with normative concepts about male and female, with culturally available symbols, economy, the State, etc. Such social practices are "gendered" instances, fields of knowledge or cultural practices. All culture and society as a whole are constituted by representations - always multiple, provisional, and contingent—of male and female; at the same time, they produce or resignify these representations (Meyer 2004, 15).In short, different social practices reproduce hegemonic gender cultural values and meaning, but also lead them to action, by reinforcing them, and by "gendering" individuals from those norms.

Thus, much as in other social categories, such as race, ethnicity or class, gender refers to the building of social identities. And it is also connected to symbolic and ranking systems that are created by means of language; from them, individuals position themselves as subjects.

\section{Dance, Gender, And Education:}

According to Louro (2013b) and Connel (1995), the process of educating men and women in society implies the process of teaching and learning values, postures and body movements that are regarded as masculine or feminine. Therefore, thinking about the relation between dance and gender implies calling into question the relation between body and gender, since, according to Gender Studies, we experience masculinities and femininities as t1/"certain muscular tensions, postures, physical skills, ways of moving (...)" (Connel 1995, 189).

The importance of the concept of "physical techniques" must then be pointed out: according to Mauss (1979), these are ritualized practices with which human beings tend to imitate certain ways of using their bodies. Mauss explains that they are always associated to cultural values, where the individual is socialized, for

(...) they vary not only with individuals and their imitations; they vary, above all, with different societies, processes of education, conveniences, fashions and prestiges (Mauss 1974, 404)

This way, Mauss refers not only to physical bodily behaviors that are consciously mimicked, but also to the unconscious realm, thus comprising formal and non-formal learning processes (including the so-called "traditional dance teaching", a model based uniquely on copy and repetition), as well as informal learning process (Andreolli 2017). For Mauss, physical techniques are classified and vary, among other things, according to the expectations and values every society builds for the sexes. Thus, there is a very close relation between this concept and what Judith Butler calls gender "performance", insofar as the body is the "locus" where discourses are written, and where gender is reproduced as performative behavior.

Various studies have pointed out that, whereas sports are predominantly signified as male experiences, and related to supposedly virile personality traits (Cook et al. 2014), dancing is considered an effeminate activity, and suspicious for a male body (Sanderson 2001; Souza 2007; Santos 2009a; Santos 2009b, Andreoli 2011, Migdalek 2015).Because of that, mostly women look for dance classes in non-formal spaces (Green 2001, 2004; Shapiro 2008). Also, the number of female dance teachers is predominantly higher than male teachers (Risner 2014). 
Since dancing is often linked to a feminine ideal-that is, a hegemonic gender representation-, lessons on femininity taught in dance class are often the same ones that are taught elsewhere: to be silent, to obey, to be gracious and pretty. This way, many dance classes reinforce social expectations towards women (Stinson 1988; Santos 2009b), and so produce female subjectivities that conform to certain gender norms. On the other hand, the same hegemonic representations lead to stigmatization and bullying of male dancers (Polasek \& Roper 2011; Risner 2014).

Even though dancing is predominantly seen as a female activity, men have always danced, throughout history. But the gendering of some dances to this day comes from a narrow understanding of what it means to be male, and so it causes many men to be reluctant in taking part of dancing activities. One example of that is classical ballet, a dance whose physical techniques are perceived as "feminine" and where, usually, there are less male dancers.

In other styles, social prestige acquired by performing of physical techniques allows for the legitimizing of a male identity, so that certain dances have more male dancers (Holdsworth 2013). Urban dances, for example, can increase boys' popularity and attractiveness, given how meaningful they are as a symbol of masculinity (Pascoe 2005; Santos 2009a). This reinforces standards of physical techniques that are associated with dominant representations of masculinity, connected to symbols of domination, strength and virility. Also, it limits or makes it difficult for female dancers to participate (Wheler 2005).

Thus, when dance and gender intersect, two dimensions reveal their mutual influence: on the one hand, gender regulates a dancer's life choices; on the other, the dance they produce spread and broadcasts gender representations. That is, dancing is influenced by cultural and moral values that are constructed about what it means to be male and female, by how meaning is attached to the dancing body from dominant gender representations; at the same time, it puts meaning into practice, defining and regulating what is understood by a physical performance more adequate to men or women, reproducing behaviors, postures and physical techniques that are associated to what is considered masculine and feminine life styles. In brief, dancing is gendered and genderifying (Andreoli 2018).

From the 1970s until today, many artistic aesthetics have been proposed that go against dominant dancing representations of gender and body. A symbiotic exchange among various forms of social criticisms has occurred, brought forward by changes in social relations, advances in social movements (Feminist, LGBTQs, Queer) and artistic production.

(...) Biologizing conceptions, which establish sexual binarism, are more and more problematized and deconstructed in contemporary art forms (...) However, what can be generally accessed in dancing artistic productions - and I refer specially to stage productions - still carries a lot of the historic weight of this binary construct, a remnant of late nineteenth century romanticism. (Berghauser 2013, 6)

Nowadays, dance education is highly influenced by what Louppe (1994) called "dance movement new philosophy", and has become part of contemporary dance history along the twentieth century. Such pedagogical paradigm proposes the deconstruction of ideal dancing bodies, emphasizing the subjective and kinesthetic experience of moving bodies, self-discovery and the building of an "expressive" body; it is an important contributing factor for disrupting of imposed standards on dancing by gender norms.

However, one needs to be careful not to assume a linear and deterministic relation that would reduce the complexity of pedagogical actions to only didactic and methodological approaches. For, whether we talk about so-called 'traditional' models of dance teaching that allow for little creativity, or about contemporary proposals - as it happens in the artistic field - one is never free from reproducing gender norms and standards.

These elements point out to the relevance of the present topic: dance teaching in formal environment and the implications of gender dimensions in classroom. Since dancing is common practice in all human societies, and since bodies are essential to its aesthetic experiences, it understandably has a potential for changing values and gender references. Dancing can be a tool for deconstructing behavioral standards that are rooted in dominant representations of gender and sexuality.

\section{Methodology and Objectives}

The present study investigates the behavior of elementary students who took part of a project developed by the institutional scholarship for beginning teacher program (PIBID, in the Portuguese acronym) at Universidade Estadual do Rio Grande do Sul (UERGS, Brazil), promoted by the Teacher Training Course in dance. PIBID, a federal initiative by CAPES (Coordination for the Improvement of Higher Education Personnel, in the Portuguese acronym), acts in Brazil as a means of incorporating Teacher Credential Degree students from Higher Level Institutions (IES, in the Portuguese Acronym) into Brazil's elementary schools of the public network. Its goal is to develop didactic and pedagogical activities carried out by the students and advised by university professors. 
From a qualitative research methodology of ethnographic background, and by using participating observation, my focus was on gender relations in dance classes. The observation period, which was also the time for pedagogical intervention by the trainees, was of four months. Research goal was to observe situations that could articulate gender issues, in students and teachers' speech and behavior. In the research, we include analysis of relationships between: a) boys and girls; b) boys and boys; or c) girls and girls. Also, I focus on d) the analysis of the teacher's didactic and pedagogical performance, with the goal of problematizing the role s/he can have towards gender issues.

In this sense, the main goal is to identify how much gender power relations, norms and dominant cultural values are reproduced, and to what extent there is resistance towards them in dance classes. Finally, analysis is presented of how much dance classes can function as instances of both reproducing dominant norms of gender and sexuality, and a space for critically problematizing or resisting them. By using such devices, my goal is to contribute for the constant reflection on how gender issues help in educating dance teachers in university levels.

The research field was the Escola Estadual José Pedro Steigleder, an elementary school in the city of Montenegro, in the state of Rio Grande do Sul, Brazil. The teachers who took part on the Program and who taught classes themselves are Teaching Certificate Dance Students at Universidade Estadual do Rio Grande do Sul. Students who attended dance classes were young teenagers from 8th and 9th grades, who have flunked any grade in elementary school. All of them were poor students, boys and girls of various ethnic and racial profiles. Observations were registered in a field diary and analyzed.

\section{Results And Discussion:}

The group observed was initially composed by fifteen students, but two girls gave up and a third girl had to quit for maternity leave. The teacher developed a number of activities, aiming to help students explore qualities in body movement, according to syllabus and propositions for dancing.

One of the exercises proposed was to position students in circle so that they threw colored balls to each other. Each color corresponded to an action or body movement, to be later performed in the middle of the circle. During exercise, boys would throw more balls either to other boys, to the teacher or to the researcher-observer. Girls were often neglected, as if they were not in the circle. This evidenced the existence of a level of exclusion that, despite being greatly unconscious, reflected the existence of a hierarchy that is present in socializing models of relations between boys and girls.

The same group also developed another collective activity; it also consisted of a game in circle, where a student should pay attention to receive an imaginary ball from a classmate and pass it on, looking in the eyes of the next person who should receive the ball. Again, different behavior was perceived between the two sexes. Since there was a competitive element, where those who missed a movement or did not execute it had to leave the circle, we perceived that girls missed mostly and left the circle first, right on the early rounds of the game.

Similarly, international literature has pointed out significant gender differences in male and female student participation in dance classes. A study conducted by Willis (1995), involving 800 boys and girls in a dance program at a USA elementary school, concluded that boys occupy more space, use more physical energy, move faster, and accept more risks in dance classes Girls work in more limited spaces, move more moderately, do not expose themselves to physical risks and spend considerable amounts of time being still and preoccupied in showing themselves.

Louro $(2007,11)$ remarks that gender and sexual identities are composed and defined by social relations, which are "shaped by a society's power network". A body's behavior, during dance classes, reveals how certain social hierarchies between the symbolic universes considered "male" and "female" are constituted in our culture. Thus, it is important to consider that there is a whole apparatus of discourses that produce male bodies as bodies that present "naturally" a more fit physiological set to function actively.

A third activity was proposed, where each student had to walk around in the room with a baton in hand and, when the teacher signalized, students should position themselves in pairs, and offer physical resistance by pressing batons against each other. The goal was to exercise attention for readiness that is needed for quick reaction, an important ingredient for potentializing body expressiveness in dance. I saw that girls did not separate during free walk in classroom, and follow each other at all times. So much that, when the teacher clapped for students to make up pairs, girls would always tend to stay together, thus avoiding doing the exercise with boys.

This shows a point that is often discussed in gender studies on education, namely how difficult it is to integrate boys and girls in the same activity. In the same study by Willis (1995), cited above, the author observed that, when working with mixed groups, boys easily take leadership, whereas girls frequently complain that boys do not cooperate. From the observing situation described above, in the same baton exercise, there was evidence such spatial and physical separation happened, in the context observed, for girls did not wait for boys to cooperate: 
During the sequence, a girl and a boy pair up and exercise resistance, using their batons. The girl is bigger and stronger than the boy. The boy increases his tonus, and does not allow for the girl to display more strength, pushing her. His opposition is so strong that both of them end up dropping their batons on the floor. (Field Diary). Louro (2013) says that gender intersects pedagogical stances that are inserted in society, for the building of bodies that are "educated" within certain norms. By "educated", one understands the bodies that are nourished and built up from cultural, historical and social practices.

For Louro (2007, 16), "by classifying subjects, society as a whole establishes divisions and labels that aim at fixating identities. It defines, separates and, with subtlety or violence, also distinguishes and discriminates". The contexts described above make it possible to see that these abruptly violent forms of establishing physical and symbolic borders between male and female universes are present in body dynamics that are practiced in dance classes.

Studies on masculinity (Kimmel 1998; Connel 2013) observe that dominant models are still guided by features such as competition, individuality, hierarchy, domination, and physical strength. Notwithstanding, it is important to highlight that constructing dominant masculinity does not follow a fixed or unified axis, and that dominance can be changing, depending on context and on socio-cultural settings. Following this line of thought, boys who have attended the dance classes observed, when faced with the didactic setting of a mixed class, where activities were not differentiated for the sexes, established this difference between male and female universe by reinforcing the attributes of what Connel (1995) calls "dominant masculinity".

Many studies show that, even though they were initially intimidated by being involved in practices that society sees as "female", once they start dancing professionally, in companies and art groups, men have many privileges, when compared to women: better salaries, stage roles of more prestige or higher positions. (Meglin \& Brooks 2012; Wright 2013;Risner 2014; Allen-Collinson, Clegg and Owton 2016). Power relations established among young male and female students in classroom are related to power relations that are widely observable in society. And young males' attitudes reproduce in smaller scale what society as a whole reproduces from hierarchical values.

In non-competitive activities, when the teacher asked students to build choreographic scores from free creative movements and physical gestures, boys would usually lead. Girls would watch, without interrupting or adding up. In these classes, boys and girls often tended to split into two groups. In this case, much as in those previously described, the teacher did not interfere.

Another situation, evidenced during research, happened when the teacher proposed that the group created soft, light and delicate movements. Boys resisted intensely in performing the task proposed. Initially they refused to perform the task, by saying that only the girls should do it. Saraiva (2013) discuss the matter of dance movements that can or cannot be performed by boys and girls so that they do not "lose their sexual identities."

It is worth mentioning here the role the teacher attempts to have towards gender issues. It is important to notice that, from the start, when planning activities, she did not try and work with the notion of differentiating "female" and "male" movements. This establishes a conflict between what she proposed and the possible references the male students had. However, in this case, unlike the previous ones, the teacher interferes. And she does it by standing her ground and saying that everyone would have to work with all sorts of movement.

In a different situation, during a physical exercise, the teacher proposed to the students the creation of gestures that showed they were in love. Here, the female students took the lead, rather than the boys. Also, they created quite different and varied gestures among themselves. The male students, on the other hand, more or less repeated each other's movements, with less variability.

Some studies (Santos 2008a; Santos 2008b) observe that, when socialized within cultures that present strong gender binarism, men and women that dance tend to perpetuate gender dichotomy by marking certain dances, or certain sets of gestures, body movements or costumes as "female" or "male". This assumption, quite rooted in common sense, that there is a "male" and a "female" way of dancing, already given by Nature, is opposed to the evidences brought forth by Gender Studies.

Such studies have evidenced that symbolic constructions that limit bodily aesthetic possibilities in dance, by placing the body within a binary opposition, do not dissociate themselves from other dimensions in people's lives, which relate to some personal attitudes, to social status and even to economic positions, etc. This is discussed in the studies aforementioned, but also in Souza (2007) and Andreoli (2011), which refer to professional art dance companies. This shows that some movements and gestures in dancing, interpreted by cultural meanings, and from a gender perspective, articulate certain values and expectations referring to how men and women position themselves and behave in society. 
Many days later, and due to the teacher's insistence, the male students accepted performing the softer, lighter and more delicate movements. However, it is important to acknowledge that they did not perform them clearly, that is, with the same intention or dedication given to performing stronger and more firm movements, probably for considering these to be more "male-like". And even when they already executed the soft and delicate movements without complaining, still they did it timidly, showing embarrassment. In a different situation, the teacher proposed that students developed a choreography from what they had done so far, in order to present it at the Dance Festival that would take place at the school, at the end of the semester.

This event was created by the training teachers from PIBID and happened once a month. The boys immediately said they did not want to participate, whereas the girls responded that, for them, presenting it or not made no difference.

During another class, after two months of activities, one of the boys said he was more motivated to performing the dance activities proposed. He positioned himself in front of the others, showed more concentration and interest in performing the movements. But he kept looking back at all times and tried to check the other boys' reactions, as they were looking at him. After class, the same student, who was interested in showing the choreography on the Dance Festival, agreed with his friends and said he would no longer take part.

This shows the relational character (Scott 1995) of identitarian gender constructs, and how validation and legitimacy of "true" and authentic masculinity happens from male-to-male relations. Being interested in dancing seems to place this boy's masculinity under suspicion. And it displays the active character of how gender regulatory norms act. For, even after showing that he enjoyed dancing, the boy eventually did not want to perform in front of others, for he expected to be judged by them. In this social context, an active investment in regulating ways of being masculine in dance, by supervising postures, movements, gestures, costumes, etc, is evidenced, even when there is no verbal pressure otherwise.

\section{Final Remarks:}

This article attempts to contribute for the pedagogic reflection on dancing, based on knowledge proposed by gender studies for education in general. It showed that, in dance classes, social relations between male and female students reflect existing hierarchies between men and women in society, making it difficult for them to interact in mixed classes, and often expressing situations of micro-violence, where young females are subtly excluded. Also, often times, teachers were neutral when such social hierarchies were reproduced. This points out the importance of reflecting pedagogically on the subject, and for teachers to be ready for sensitizing dance students' perceptions on gender inequalities in dance classes.

This study also argues that gender builds different meanings between male and female students, about living and experiencing their bodies in dancing, even when more contemporary methodologies are applied that allow for greater freedom in movement creation. In the situations observed, the teachers stimulated the transposing of body standards that are imposed by gender norms. However, such actions were limited to the male students, who, from the start, had profiles of more limited creativity. On its turn, it represented an important way to relativize notions of "feminization" of some quality dance movements, allowing boys to dance out of gender norms, thus creating tension in dominating masculinity standards.

This study points out some possibilities for dancing teaching that pays more attention to diversity on gender issues. And it shows that any perspective on dancing teaching that tries to be aware and responsible must take into account the complex process of gender construction, from which dancing can often work to perpetuate cultural standards. Seemingly insignificant attitudes, such as teaching students that there are "male" and "female" dance movements, can contribute for perpetuating limited conceptions of gender, which are linked to producing sexist, heteronormative or transphobic social practices. Dance teachers have a leading role, in this regard. It is important that their didacticmethodological performance always be concerned with problematizing how they can act towards an education that fosters plurality.

\section{References}

ALLEN-COLLISON, Jacquelyn, CLEGG, Helen; OWTON, Helen (2016). The "cool stuff": Gender, dance and masculinity. Psychology of Women's Section Review, Special Issue on Sports, v.18, n.2, p6-16.

ANDREOLI, Giuliano Souza (2018). Representações de masculinidade na dança contemporânea. Revista Movimento, v. 17, n. 01, p. 159-175.

ANDREOLI, Giuliano Souza (2018). A Técnica Corporal na Dança: redimensionamentos epistemológicos. Revista Arte da Cena, Goiânia, v.3, n.2, p.89-111, jul-dez. 
ANDREOLI, Giuliano Souza (2018). Dança, gênero e sexualidade: narrativas e performances. Novas Edições Acadêmicas, Beau Bassim, Mauritius.

BEAUVOIR, Simone de (1967). O Segundo Sexo. Volume 2: A experiência vivida. Difusão Européia do Livro, São Paulo.

BERGHAUSER, Tatiana Araújo (2013). Problematizações sobre enfoques de gênero reducionistas ou distorcidos na Dança. Artigo (especialização). Programa de Pós-graduação em Dança, UFBA, Salvador.

BRITZMAN, Deborah (1996). O que é esta coisa chamada amor? - identidade homossexual, educação e currículo. Revista Educação e Realidade, Porto Alegre, vol. 21, n.1, p.71-76, jan-jun.

BUTLER, Judith (2001). Corpos que pesam: sobre os limites discursivos do "sexo". In: LOURO, Guacira Lopes (ed). O corpo educado: pedagogias da sexualidade. Belo Horizonte: Autêntica.

BUTLER, Judith (2001). Problemas de gênero: feminismo e subversão da identidade. Rio de Janeiro: Civilização Brasileira.

CONNEL, Robert William (1995). Políticas de Masculinidade. Educação e Realidade,v .20, n. 2, jul/dez, p.185-206.

CONNEL, Robert William \& MESSERSCHMIDT, James (2013). Masculinidade hegemônica: repensando o conceito. Estudos Feministas, Florianópolis, v. 21, n.1, p.424, janeiro/abril.

CORREIA, Clara Pinto (2004). O Testículo esquerdo: alguns aspectos da demonização do feminino. Lisboa: Relógio D'Água Editores. Relógio D'Água Editores.

CLIFFORD, James (1986). On Ethnographic Allegory" in Cliffor, James e Jeorge Marcus (orgs.). Writing Cultures: The Poetics and Politics of Ethnography, Berkeley, Los Angeles, Lonfdon: University of California Press. .

HANNA; Judith Lynne (1999). Dança, Sexo e Gênero: signos de identidade, dominação, desafio e desejo. Translated by: Mauro Gama. Rio de Janeiro: Rocco.

HOLDSWORTH, Nadine (2013). 'Boys don't do dance, do they?', Research in Drama Education: The Journal of Applied Theatre and Performance, v.18, n.2, p.168-178.

JESUS, Jaqueline Gomes de (2012). Orientações sobre identidade de gênero: conceitos e termos. Brasília. 42 p.

KIMMEL, Michael Scott (1998). A produção simultânea de masculinidades hegemônicas e subalternas. In: Horizontes Antropológicos. Corpo, doença e saúde. Porto Alegre: Porto Alegre: PPGAS/UFRGS, ano 4, n.9, out, p.103-17.

LAQUEUR, Thomas Walter (2001). Inventando o Sexo: corpo e gênero dos gregos a Freud. Translated by: Vera Whately. Rio de Janeiro: Relume Dumará.

LOURO, Guacira Lopes (2013b). Gênero, Sexualidade e Educação: uma perspectiva pós-estruturalista. Rio de Janeiro: Vozes.

LOURO, Guacira Lopes (2013b). (ed). O corpo educado: pedagogias da sexualidade. Belo Horizonte: Autêntica Editora.

LOURO, Guacira Lopes (2013b). Um corpo estranho: ensaios sobre sexualidade e teoria queer. Belo Horizonte: Autêntica Editora.

MAUSS, Marcel (1974). As Tecnicas Corporais. In: Sociologia e Antropologia. vol. 2. São Paulo: E.P.U./EDUSP.

MEGLIN, Joellen (2012). A., \& BROOKS, Lynn Matluck. Where are all the women choreographers in ballet? Dance Chronicle, v. 35, n.1, p.1-7.

MIGDALEK, Jack (2015). The Embodied Performance of Gender, v.43, London, United Kingdom: Routledge. Routledge.

MEYER, Dagmar Estermann (2003). Gênero, Sexualidade e Educação: Teoria e Política. In: LOURO, G.L., NECKEL, J.F. \& GOELLNER, S.V. (eds). Corpo, gênero e sexualidade: um debate contemporâneo em Educação. Petrópolis, RJ: Petrópolis, RJ: Editora Vozes, p.9-27.

NICHOLSON, Linda (2000). Interpretando o gênero. Revista Estudos Feministas. 8 (2).

PASCOE, Cheri J. (2005) 'Dude, You're a Fag': adolescent masculinity and the fag discourse. Sexualities, v.8, n.3, p.329-346.

POLASEK, Katherine M. \& ROPER, Emily A (2011). Negotiating the gay male stereotype in ballet and modern dance. Research in Dance Education, v.15, n.2, p.179-201.

PRECIADO, Beatriz (2014). Manifesto Contrasexual. Políticas subversivas de identidade sexual. São Paulo, n.1. Edições.

RISNER, Doug (2014). Bullying victimisation and social support of adolescent male dance students: an analysis of findings. Research in Dance Education, v.15, n.2, p.179-201.

SANDERSON, Patrícia (2001). Age and gender issues in adolescent attitudes to dance. European Physical Education Review, v.7, n2, p. 117-136.

SCOTT, Joan (1995). Gênero: Uma categoria útil de análise histórica. Educação e Realidade, Porto Alegre, UFRGS, v.20, n.2, p.71-79. 
SANTOS, Éderson Costa (2009a). Um jeito masculino de dançar: pensando a produção das masculinidades de dançarinos de hip-hop. 124 p. Master Thesis - Programa de Pós-Graduação em Educação, UFRGS, Porto Alegre.

SANTOS, Tatiana Mielczarski (2009b). Entre pedaços de algodão e bailarinas de porcelana: a performance artística do balé clássico como performance de gênero. 95 p. Dissertação (Mestrado) - Programa de Pós-graduação em Educação, UFRGS, Porto Alegre.

SOUZA, Andréa Bittencourt de (2007). Cenas do masculino na dança: representações de gênero e sexualidade. Ensinando modos de ser bailarino. Dissertação (Mestrado), Programa de Pós-graduação em Educação, ULBRA, Canoas.

STINSON, Susan (2005). The hidden curriculum of gender in dance education. Journal of Dance Education, v. 5, n.2, p.51-57.

WELLER, Wivian (2005). A presença feminina nas (sub) culturas juvenis: a arte de se tornar visível. Revista Estudos Feministas, Florianópolis, v.1, ano 13, p. 107-126, jan./abr .

WILLIS, Cheryl M. Factors thar affect dance programs. Journal of Physical Education, Recreation e Dance, v.66 (n.4). 58-63.

WRIGHT, Jan (2013). Male dance educators in a female-dominated profession, Journal of Physical Education, Recreation \& Dance, v. 84, n.7, p.14-15. 